\title{
Fiscal crisis in Brazil: causes and remedy
}

\author{
Crise fiscal no Brasil: causas e remédio
}

MÁRCIO HOLLAND*

RESUMO: De 2014 a 2017, o Brasil experimentou uma deterioração fiscal sem precedentes causada por fatores multidimensionais. De acordo com a literatura econômica, para lidar com tal crise, é recomendado adotar um programa de consolidação fiscal baseado em corte de gastos mais do que baseado em aumento de impostos. Contudo, a forma como a crise evoluiu recentemente no Brasil traz uma nova perspectiva de orientação de política fiscal. O artigo sugere um programa de consolidação fiscal combinando tanto corte de gastos quanto aumento de impostos. De um lado, a peculiaridade dos gastos governamentais brasileiros demanda reformas com impactos duradores, mas geralmente apresentam baixo impacto fiscal de curto prazo. De outro lado, como os resultados fiscais de curto prazo ancoram a confiança, aumentos em impostos seriam pilar importante da política econômica para mitigar a deterioração fiscal no curto prazo. É esperado que a contração do PIB seja mais severa do que no caso de simples medidas de corte de gastos, mas provavelmente a contração seria menos prolongada.

PALAVRAS-CHAVE: Crise Fiscal; Economia Brasileira; Ajustamento Fiscal; Programa de Consolidação Fiscal.

ABSTRACT: From 2014 to 2017, Brazil experienced unprecedented fiscal deterioration caused by multidimensional factors. According to the economic literature, to cope with such a crisis, it is recommended to adopt a long-term spending cut-based fiscal consolidation program rather than a tax hike-based one. However, as the fiscal crisis evolved recently in Brazil, this article brings another perspective to the policy stance. It suggests a fiscal program that includes a combination of spending cuts and tax hikes. On one hand, the peculiarities of the Brazilian government expenditures demand fiscal reforms with long-lasting impacts but generally with low short-term fiscal effect. On the other hand, as short-term fiscal results anchor confidence, increases in taxes would be an important pillar of the economic policies to mitigate the fiscal deterioration in the short term. The GDP contraction is expected to more severe than a simple spending cut measure but is likely to be less prolonged.

KEYWORDS: Fiscal crisis; Brazilian Economy; Fiscal Adjustment; Fiscal Consolidation Program.

JEL Classification: H30; H60; H12; H61.

\footnotetext{
* Escola de Economia da Fundação Getulio Vargas, São Paulo - SP, Brasil. E-mail: marcio.holland@fgv. br. Submitted: 26/February/2018; Approved: 16/April/2018.
} 


\section{INTRODUCTION}

A few months before the 2008 financial crisis, Brazil became an investment grade country. This achievement was the result of a long period of good fiscal and monetary practices, which stemmed from the breakthrough in 1999 that included the implementation of an inflation target, the adoption of a flexible exchange rate regime, and the advent of a fiscal responsibility law. However, in 2015, due to an unprecedented deterioration of the economy and subsequent decline in fiscal results, Brazil was demoted to speculative grade.

This article assesses the misfortune of an economy that lost its luster much sooner than expected. This article is an effort to unveil what occurred, and therefore, it proposes an appropriate fiscal adjustment for such circumstance. First, it presents the way in which the fiscal results have evolved over time by seeking the main drivers of the deterioration. Second, it assesses the countercyclical policies proposed in the aftermath of the 2008 financial crisis and their effectiveness. Then, the article evaluates the shortcomings of both the unsuccessful 2015 fiscal adjustment and the 2017 fiscal reforms.

The article highlights the structural features of the Brazilian government's consumption as well as several social policies adopted during the 2000s that contributed to the fiscal collapse. The main aim is to show that the fiscal crisis that started in $2014^{1}$ has many plausible explanations, including the rigidness of the federal budget, comprehensive social programs that originated in the Lula administration (2003-2010) and were widely extended during Dilma's administration (2011-2016), and finally, the exhaustion in the Brazilian model of growth. Most countercyclical fiscal policies implemented in the wake of the 2008 international crises turned out to be ineffective and more importantly left increasing public debt for the coming years. As a sort of perfect storm, an unprecedented political and moral crisis started just after the 2014 presidential election, dragging the country into disarray.

Due to the multidimensional causes of this crisis, recovery requires a combination of both long-lasting spending cuts and increases in taxes to strengthen short-term fiscal results. The main result expected with such a strategy is a reduction in the duration of the recession rather than in the severity in the recession. In our country's case, the recession lasted for eleven quarters in total and yielded a contraction of more than $7 \%$ of GDP due to hesitation in adopting an appropriate fiscal consolidation plan. With the adoption of a comprehensive fiscal policy framework, the recession would have been shorter, although not necessarily less severe.

\footnotetext{
${ }^{1}$ When reviewing this manuscript in January 2018, it was hard to define the timespan of this crisis, since increasing debt-to-GDP ratio and primary deficits are foreseen until at least 2022.
} 


\section{RELATED LITERATURE}

The topic of this article is related to the discussion of the effectiveness of fiscal policy mostly associated with the fiscal multiplier, either for government purchases or tax revenue. However, the literature indicates that there is no unique fiscal multiplier. Furthermore, literature on emerging market economies is scarce and lacks theoretical support for whether multipliers should be expected to be higher or lower in emerging economies relative to advanced economies (Estevão \& Samake, 2013; Ilzetzki et al.,, 2013; Ilzetzki, 2011; IMF, 2010; Kraay, 2012). Some studies even conclude that multipliers are negative, particularly in the longer term (IMF, 2010) and when public debt is high (Ghosh \& Rahman, 2008).

One can easily find very divergent fiscal multipliers. The multiplier depends on critical factors such as trade openness, the exchange rate regime, the fiscal instrument (whether spending - or tax-based), the debt level, the monetary policy stance (whether normal or zero-lower-bound), and the state of the economy (whether contracting or expanding). Despite such innumerable factors, the fiscal multiplier is also sensitive to the method of estimation. For instance, the DSGE (dynamic stochastic general equilibrium) approach has shown larger multipliers than the VAR approach. However, as highlighted by Mineshima et al., (2014:319), the DSGE model presents difficulties in modelling nonlinearity and does so differently compared with the Taylor rule for monetary policy, as "there is no widely accepted fiscal policy (rule) to be included in a DSGE model".

On the other hand, VAR models are subject to several criticisms. Commodityexporting countries, such as Brazil, may experience revenue changes because of booms and busts in the international commodities market and not because of discretionary fiscal policy. As VAR models suffer from the omitted variable problem, and the required quarterly data might not be available for a long enough time span, they can limit identifying information. In the specific case of Brazil, the longest possible time span results in 72 observations over the course of 18 years, including the last years of a pegged exchange-rate regime (1997-1998). According to Ilzetzki (2011), the more fixed the exchange rate regime, the larger the fiscal multiplier. Therefore, our results may be biased when we use the full sample (1997-2014).

Brazil is considered a closed economy, and this attribute is expected to increase the fiscal multiplier. As Brazilian trade openness does not present relevant changes over time, we do not expect any sort of influence of such a key variable on the identification of the multiplier using country-specific VAR models. Although trade openness is highly recommended for many other reasons, if policymakers are interested in using a discretionary fiscal policy to obtain any real output effect, the current closed economy makes their fiscal efforts more effective. However, if the effectiveness of the fiscal policy falls short of policymakers' expectations, trade policy should be implemented to achieve increased economic opening.

Many efforts have been made to show the importance of fiscal instruments. As is widely known, spending-based fiscal consolidation policy can be more effective than tax-based policies, and the fiscal multiplier of the former is likely to be high- 
er than that of the latter. Moreover, the procedure of Alesina et al., (2014) involves a simulation of a multi-year fiscal plan rather than of individual fiscal shocks. According to the authors' findings, "Fiscal adjustments based upon spending cuts are much less costly, in terms of output losses, than tax-based ones and have especially low output costs when they consist of permanent rather than stop and go changes in taxes and spending". As the authors explain, "The difference between tax-based and spending-based adjustments appears not to be explained by accompanying policies, including monetary policy. It is mainly due to the different response of business confidence and private investment”.

The debt level is very important, especially with the debt threshold below the international threshold, as in the Brazilian case. According to the economic literature, the lower the debt threshold is, the smaller the fiscal multiplier. In Ilzetzki (2011), the fiscal multiplier can eventually become negative when the debt exceeds its threshold. Brazil obtained sound results in terms of net debt levels until at least 2013; the gross debt-to-GDP ratio is higher than those of its peers, and debt maturity has remained a concern. The implicit interest rate of the debt is much higher than the monetary policy rate, which is considered one of the most persistently high in the world. Because of this debt constraint, Brazil is expected to show a small fiscal multiplier. In other words, fiscal stimuli are welcome during contractions, without losing sight of debt sustainability in the medium term.

The state of the economy is one critical factor of the effectiveness of the fiscal policy as measured by fiscal multiplier. Using regime-switching models, Auerbach and Gorodnichenko (2013) estimated the effects of fiscal policies that might vary over the business cycle. They found considerable differences in the size of spending multipliers during recessions and expansions, with fiscal policy being considerably more effective in recessions than in expansions. Brazil's output ran well below its potential level throughout the period from 2014-2017, as roughly measured by the HP filter. In this scenario, the fiscal multiplier is expected to be larger than that in previous years. Puzzlingly, fiscal stimuli seemed not to be effective at all.

As is well known, the effectiveness of fiscal policy is heterogeneous under normal circumstances (Favero, Giavazzi \& Perego, 2011). In the case of conventional monetary policy, fiscal laxity may have a restricted impact on output. Otherwise, countercyclical fiscal policy is likely to smooth the business cycle. The debt level is a constraint in both cases but is most likely a major issue for developing economies. In line with Easterly's (2013) idea, part of the public debt increase is considered "normal" in advanced economies. However, in the aftermath of the 2008 turmoil, conventional monetary policy has been used mostly in developing economies, where debt intolerance (Reinhart et al.,, 2003) is still considered a relevant phenomenon.

\section{CAUSES OF THE FISCAL CRISIS}

Governments across the globe responded to the 2008 crisis with unprecedented expansionary action in recent economic history. Monetary and fiscal counter- 
cyclical actions were implemented both to stymie the contamination of the international crisis in financial systems and to resume growth as soon as possible.

From 2008 to 2010, fiscal and monetary stimuli were overwhelmingly recommended. However, since 2010, the focus has shifted to fiscal consolidation in advanced economies. Since then, fiscal results have improved around the world, although debt-to-GDP ratios remain high compared to those before the crisis.

The fiscal front has deteriorated dramatically in many advanced economies with mixed and unspectacular results. However, in comparing the 1929 Great Depression with the 2008 Great Recession, Eichengreen (2015:2) reflects on these crises as follows: "As a result of this different response, unemployment in the United States peaked at 10 percent in 2010 . Though this was still disturbingly high, it was far below the catastrophic 25 percent scaled in the Great Depression”.

Based on this argument, the Brazilian government adopted a series of countercyclical policies to protect the local economy from crumbling. These policies seemed to work well, at least until 2011. The worst of the crisis was absorbed without any major disruption in the Brazilian economic system. Most importantly, the economy resumed growth in the $2^{\text {nd }}$ quarter of 2009; the unemployment rate did not spike; real wages continued to grow; and consumer and business confidence recovered very quickly.

In early 2011, the Federal Administration was able to start applying a fiscal consolidation plan to calm the economy. Needless to say, solvency had not been a problem in Brazil for a long time because international reserves had been considerable and more than sufficient to pay for external liabilities; in addition, the public debt-to-GDP ratio had been decreasing for years.

Due to Brazil's reaction to the crash, the general gross debt-to-GDP ratio increased by $3.3 \%$ from 2008 to 2009 , which is considered an incredibly low rate in comparison to the debt dynamics in advanced economies after the crisis. However, the general gross debt-to-GDP ratio was already high in Brazil compared to that of its peers; at the same time, it had been relatively stable, even during most of the period involving the countercyclical fiscal policy.

Even with such policies, the primary surplus targets were fully met, at least until $2012^{2}$. However, by mid-2012 to 2013 , the recovery appeared to be weaker than expected, and the Brazilian economic authorities returned to using incentives in an attempt to reignite the economy ${ }^{3}$. In 2013 , the economy grew by $3.0 \%$ and

\footnotetext{
${ }^{2}$ Although the one-off revenues had increased in importance after the 2008 crash - corresponding, for instance, to $0.74 \%$ and $0.85 \%$ of the GDP in 2009 and 2010 , respectively, when the full primary surplus was $1.9 \%$ and $2.6 \%$ of the GDP, respectively, or in 2013 , when $0.68 \%$ of $1.8 \%$ of the GDP was one-off revenue. In 2014, the one-off revenue was $0.5 \%$ of the GDP, while the primary deficit was $0.6 \%$ of the GDP.

${ }^{3}$ At that time, estimates of GDP growth were $2.7 \%$ for 2011 instead of $3.9 \%$, as reported in the new 2015 dataset, declining towards $0.9 \%$ in 2012 instead of $1.8 \%$ as reported in the new 2015 dataset. Moreover, the share of investment over GDP was sharply declining, but the new 2015 dataset unveiled very stable figures for this indicator.
} 
investment by $5.8 \%$. A broad tax relief program and increasing government expenditures, including a financial subsidy for credit for capital goods via public banks, was again introduced.

Nevertheless, after a period of recovery - reaching its peak in 2010, when the economy grew by $7.5 \%$ - the overall growth remained at approximately $2.9 \%$ per year (2011-2013) with very rapid deterioration in 2014 and a strong contraction in 2015-2016; only in 2017 did a typical cyclical recovery start to occur.

From 2013 to 2014, the output did not respond at all to tax stimuli or even spending increases. After Brazil responded to the 2008 crisis by using countercyclical fiscal policies (Vègh \& Vulletin, 2013), a rapid deterioration occurred on the fiscal front in 2014, along with other events. The net and gross public debt soared quickly towards a risky case scenario, so investment grade ratings were no longer assured. In September 2015, a few weeks after the government had decided to propose the 2016 Budget Law with a deficit to Congress, Standard \& Poor's downgraded the Brazilian sovereign rating to the speculative grade. A few months later, Fitch and Moody's followed suit.

Since mid-2014, the Brazilian economy has fallen into complete disarray with the combination of a fiscal crisis and a strong and prolonged GDP contraction in the midst of political chaos. It is important to highlight that the 2014-2016 GDP contraction is somehow associated with a more profound phenomenon because many analysts believe that the previous consumption-based growth model had already been exhausted. Unfavorable terms of trade are also considered an important driver of such exhaustion.

Meanwhile, the economy suffered from many other events, such as corruption scandals involving the largest Brazilian state-run oil company and major entrepreneurs in the civil construction sector, low government popularity amid street protests and general disapproval regarding the corruption scandals, several bribery schemes, a long-standing and severe drought, and the 2014 FIFA World Cup. It would be fair to include the tight monetary policy - with the central bank struggling against the loss of credibility - in the myriad of constraints and the associated curbing of household credit for durable goods.

The rapid fiscal deterioration observed since 2014 is also the result of a wide range of countercyclical fiscal policies put into practice at two different moments - in the aftermath of the 2008 financial crisis and from mid-2012 to 2014. The first round of such policies that was implemented just after the 2008 international financial turmoil appears to have been working well, and the Brazilian economy started to resume growth. After a short-lived fiscal consolidation, the Brazilian authorities decided to re-edit another tranche of fiscal stimuli, from credit subsidies to tax exemptions, in 2012. Some recent empirical studies (Matheson \& Pereira, 2016, and Mendonça, Marçal \& Holland, 2016, for instance) found that the effectiveness of the measures was far from satisfactory. The low growth led to low tax collections while the expenditures were expanding, and consequently, the primary deficits become a new reality from 2014 to 2017.

Therefore, the fiscal results had been deteriorating faster than predicted be- 
cause the tax revenue had been frustrated, in line with the growth downturn. Gross debt, as a percentage of the GDP, increased from 53.3\% in December 2013 to $58.9 \%$ in December 2014 and then soared to $74.0 \%$ by December 2017. The gross debt prospects indicate further increases to over $80 \%$ of the GDP by the end of 2020. In addition, surprisingly, the nominal deficit increased from $3.1 \%$ to $7.8 \%$ of GDP. In December 2017, a movement driven by interest payments also increased the rate to $6.1 \%$ of the GDP. Debt maturity and denomination have deteriorated with the same intensity.

As risks tilted towards deep GDP contraction in 2015-2016, fiscal sustainability became an important issue yet again. Tax revenue frustration is only a partial explanation. Government consumption has been resilient, regardless of the economic situation. Additionally, the government was not assisted by the relevant amounts of one-off revenues that have been used in the last few years to deliver the announced primary surpluses; it also had to pay the delayed expenses, domestically labelled "fiscal pedalling"4 ("pedalada fiscal").

Brazil fell into a severe fiscal crisis: the country started to fail to meet the required primary surpluses - that is, the level necessary to stabilize the debt to GDP. As far as can be seen, by early 2018 , there is no prospect of primary surpluses that are sufficient for stabilizing the debt-to-GDP ratio.

The causes of such fiscal situations are closely related to the causes of the GDP contraction. However, on the one hand, some of the fiscal difficulties are due to structural features insofar as the wide spectrum of social benefits implemented since the 1988 Federal Constitution are considered. This explains part of the growing government spending related to social benefits, such as the income transfer programs and the pension benefits ${ }^{5}$ LOAS $^{6}$. The other part of such an expansion is due to a social-biased public policy implemented in the early 2000s, such as Minha Casa Minha Vida (housing program), Bolsa Família (a conditional cash transfer program), and an aggressive policy to ensure superior public education across the country (Prouni, Reuni, Fies, etc.).

The dissimilation of social benefits during the 2000s is associated with the intensification of a counter-cyclical fiscal policy after the 2008 financial crisis, which triggered government spending that was no longer financeable by increases

\footnotetext{
4 "Fiscal pedalling" became a well-known issue in Brazil; it is the main reason for the impeachment process of Dilma Rousseff. There are, in fact, at least three types of such expedients: first, the creative accounting related to the special operations used at the end of 2012 using the Sovereign Fund, BNDES and the Nation Treasury; second, the numerous delays in payments from the National Treasury to public banks that are responsible for paying social benefits in 2014; and third, the decree signed by the president expanding the 2015 budget without the Congressional allowance. This last reason became the main cause of the legal proceedings against the president in 2016.

${ }^{5}$ In 2017 , the deficit in the general pension system reached $2.8 \%$ of the GDP from $1.0 \%$ of the GDP in 2014.

${ }^{6}$ LOAS is an unconditional income transfer program for elderly and disabled people, with the benefits indexed to the minimum wage. Its expenditure reached $0.7 \%$ of the GDP.
} 
in tax revenue. On the other hand, the stronger-than-expected GDP contraction led to tax revenue frustration, even with tax rate hikes.

Additionally, a huge operation against corruption called "Car Wash" (Operação Lava Jato) was gaining ground and affecting the entire country. High-profile entrepreneurs, politicians, and bankers were involved in the scandal. Similar to a perfect storm, the political weakness of the government, due to its low popularity level, was an impediment for passing the relevant fiscal measures in the Congress. Uncertainty was amplified, and the economy deteriorated. Ultimately, President Dilma Rousseff was subjected to an impeachment process. The new government took office and renewed the desire for a fiscal consolidation process.

However, along with a bold fiscal reform agenda, the Temer government also accommodated increases in consumption, shaping a short-term expansionary fiscal policy that was expected to be severe in the long term.

\section{LIMITS TO ADJUSTMENT}

Given this dramatic situation, long-term spending-based fiscal adjustment would be a plausible recommendation for fiscal policy, as recommended by an important avenue of literature (see Alesina \& Ardgna, 2009; Alesina et al., 2014). However, the strong economic contraction and its harmful impact on confidence as well as a myriad of constitutional and legal restrictions on rapid reduction of expenditures diminish the effectiveness of a fiscal consolidation plan based predominantly on spending cuts. Approximately $90 \%$ of the total primary expenditures are not attainable through a retrenchment without changing the Federal Constitution or laws; they are simply mandatory.

Let us use the example of the 2016 Budget Law that was sent to Congress on August 31, 2015. According to the draft, $\mathrm{R} \$ 1.1$ trillion of $\mathrm{R} \$ 1.2$ trillion was mandatory and non-retrenched primary spending. The remaining $9 \%$ was discretionary, although this amount was difficult to cut given the risk of paralyzing important public policies. The pension system represents $40 \%$ of the total government consumption, followed by payroll $(21 \%)$; discretionary spending includes segments such as health, education and successful programs such as Bolsa Familia. See these figures in Table 1.

The Federal Constitution and its laws govern most of the allocation of the budgetary resources. In the case of the federal administration, it is mandatory to designate at least $18 \%$ of the net tax revenue to education and at least $25 \%$ to the states and municipalities. The federal administration and the states and municipalities must spend at least $12 \%$ and $15 \%$, respectively, of their net tax revenue on health. This indexation with the net current revenue is a source of instability in the government expenditures ${ }^{7}$. In 2015, for instance, the federal government spent

\footnotetext{
${ }^{7}$ The constitutional amendment, announced on June 15, 2016, and labelled as the "spending ceiling",
} 
$14.8 \%$ of its net current revenue on the health sector, which is above its legal minimum level.

Excluding payroll, the federal government spent $23 \%$ of its net tax revenue on discretionary expenditures. This percentage includes $4.5 \%$ to infrastructure via PAC (Programs of Growth Acceleration), including the housing program Minha Casa Minha Vida (2\%) and Bolsa Família (2.7\%). These public policies are subject to cuts according to the political preferences of the administration.

Table 1: Composition of the Primary Spending According to the 2016

Budget Law: R\$ billions, \% of GDP, and \% of Total Spending

\begin{tabular}{|l|c|c|c|}
\hline & R\$ billion & $\begin{array}{c}\% \text { of the } \\
\text { GDP }\end{array}$ & $\begin{array}{c}\% \text { of total } \\
\text { spending }\end{array}$ \\
\hline Total Spending & $1,210.6$ & $19.4 \%$ & $100.0 \%$ \\
\hline Limited-to-Cut Spending & $1,095.5$ & $17.6 \%$ & $90.5 \%$ \\
\hline Mandatory Spending & 960.2 & $15.4 \%$ & $79.3 \%$ \\
\hline Pensions & 491.0 & 7.9 & 40.6 \\
\hline Payroll & 252.6 & 4.0 & 20.9 \\
\hline FAT - Worker Support Fund & 55.0 & 0.9 & 4.5 \\
\hline LOAS - Elderly/Disabled Benefit & 46.1 & 0.7 & 3.8 \\
\hline Subsidies & 28.3 & 0.5 & 2.3 \\
\hline Payroll Tax Exemption to the Private Sector & 18.5 & 0.3 & 1.5 \\
\hline Legislative and Judiciary & 13.6 & 0.2 & 1.1 \\
\hline FCDF - Federal District Fund & 12.0 & 0.2 & 1.0 \\
\hline Judicial Sentences & 10.3 & 0.2 & 0.9 \\
\hline Other Mandatory Spending & 32.7 & 0.5 & 2.7 \\
\hline Limited-to-Cut Discretionary Spending & 135.3 & 2.2 & 11.2 \\
\hline Minimum Wage & 89.5 & 1.4 & 7.4 \\
\hline Bolsa Família & 28.8 & 0.5 & 2.4 \\
\hline Education (minimum) & 17.0 & 0.3 & 1.4 \\
\hline Civil Servant Benefits & 12.5 & 0.2 & 1.0 \\
\hline Discretionary Spending & 250.4 & 1.8 & 9.5 \\
\hline PAC (Program of Growth Acceleration) & & 0.7 & 3.5 \\
\hline Others & 42.5 & 1.2 & 6.0 \\
\hline Note: Total Discretionary Spending & 4.0 & 20.7 \\
\hline Sourc: MPOG, August 31, 20.5 & & \\
\hline
\end{tabular}

Source: MPOG, August 31, 2015.

changed the indexation of spending on education and health to IPCA, a broad consumer price index, instead of the net current revenue. This is expected to increase the discretionary space to manage such expenditures in the budget. 
In summary, the percentages of the net tax revenue that the federal government was required to spend are as follows (as of 2015): $40 \%$ on the pension system; $21 \%$ on the payroll of civil servants, including their pensions; and $22 \%$ on many other mandatory spending targets, such as wage bonuses, unemployment insurance, assistance for the elderly and disabled, tax relief and subsidies. If we add the $23 \%$ mentioned above to the non-mandatory expenditures, the total spending surpassed the net tax revenue by $10 \%$ in 2015 .

On the other hand, since the early 2000s, especially under the Lula administration, Brazil became famous for having several special tax regimes. It is important to mention the Simples (2007), a simplified tax regime for small businesses, special regimes for the oil and gas industry ${ }^{8}$, civil construction, research, development, innovation and software, electronics and appliances ${ }^{9}$, infrastructure, agriculture, etc. This program facilitated the announcement of a new special tax regime ${ }^{10}$. According to the Internal Revenue Service, the total tax relief amount reached R \$ 271 billion in 2016 - that is, $4.5 \%$ of GDP.

To complete the list, in 2005, the government decided to announce a new policy on minimum wage that led to an increase of almost $80 \%$, in real terms, until 2014. Most social benefits, including more than $65 \%$ of the pensions, are linked to this policy. In 2004, Prouni, a program that extends university education to all, and Reuni, in 2007, a program that builds new university campuses and facilities in the federal university system across the country, were implemented. Those programs came with many new professors and general civil servants.

Thus, the genesis of the 2014-2017 fiscal crisis is remote, from the Lula administration (2003-2010). The Dilma Administration (2011-mid/2016) extended benefits that had already been created without due consideration, using the prolonging of the 2008 international financial crisis as an excuse to disregard certain economic golden rules ${ }^{11}$. Moreover, during the government of Dilma, the expenditure composition changed towards a higher level of financial subsidies to the industrial sector. The manipulation of the public accounting was also remarkable.

From a long-term perspective, as observed in Figure 1, there has been a considerable change in government spending since 2003. Total federal expenditures increased from $15.1 \%$ of the GDP in 2003 to $18.1 \%$ of the GDP in 2010. Meanwhile,

\footnotetext{
${ }^{8}$ Repetro is a special customs regime that was established by Decree 3161 on $26 / 09 / 1999$ and is currently governed by Decree 6.759/2009, which provides special treatment for the import and export of specific equipment for use in the research and mining of deposits of petroleum and natural gas.

${ }^{9}$ Lei do Bem (law no. 11.196/2005) enables the reduction of the tax burden for companies investing in Research, Development and Innovation (RD\&I).

${ }^{10}$ Recently, the government announced RETAERO, a special regime for the aeronautics industry; REID, a special regime for the defense industry; payroll tax exemptions for 56 sectors; Inovar-auto, a special regime for the automotive sector; REPNBL for broadband internet establishment; and others.

${ }^{11}$ It would be fair to include the harmful intervention in the energy sector (2012), the attempt to set the internal rate of return in concessions in infrastructure (2011-2012), the intolerance of the independence of Petrobras regarding its pricing policy (2013-2014), as well as the Dilma's lack of abilities as a politician.
} 
the net total federal tax revenue increased from $17.4 \%$ to $20.2 \%$ of the GDP. During the Lula administration, government consumption increased to $3.0 \%$ of the GDP. After a strong contraction in her first year in office, President Dilma pushed spending to $18.3 \%$ at the end of her first term and to $20.0 \%$ of the GDP in 2016 . This recent increase may also be related to the GDP contraction (the denominator effect).

Until 2013, the increasing government consumption was financed by corresponding increasing tax revenue. Tax revenue had increased not only because of the tax burden, admittedly high in Brazil, but also because of the growing labor formalization phenomenon, which widened the incidence base of taxes. During the 2000s, surprisingly, while tax exemptions were allocated to several economics sectors, tax revenues increased, which occurred most likely because of the increase of the base of incidence of taxes, which is related to the high economic growth with income distribution. However, the interruption in the growth pushed the whole economy to the abyss. The spending spree of financing expenses for taxes came to an end.

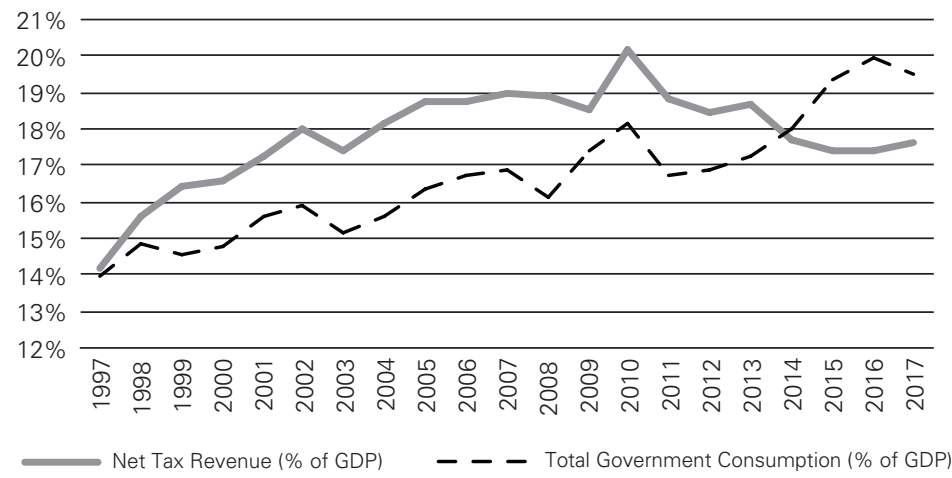

Accordingly, what are the components of the government expenditure that increased the most over time?

First, aside from government activity, from 1997 to 2015, primary spending increased to $5.3 \%$ of the GDP, while the growth of income transfers to households was approximately $4.0 \%$ of the GDP, as we can see in Table 2 . The pension benefits show the most relevant increase $(2.5 \%$ of the GDP), followed by elderly/disabledrelated benefits known as LOAS, representing $0.7 \%$ of the GDP. Part of the growth of such benefits is related to both the generous eligibility criteria and the public policy stance, as they are indexed to the minimum wage corrections. This framework was established in the 1998 Federal Constitution.

As a matter of curiosity, because of this indexation rule, the benefits increased by $78 \%$ in real terms over 10 years (2005-2014). At the same time, the number of beneficiaries of the pension system increased by 9 million people, from 23 million to 32 million. Meanwhile, the government decided to enlarge social programs such as Bolsa Família and Minha Casa Minha Vida. These two programs alone are responsible for $0.8 \%$ of GDP variation in government consumption since 1997.

Moreover, there appears to be an increase in the financial and credit subsidies related to the funding provided by the National Treasury to the state-owned banks, 
particularly to the National Development Bank (BNDES). According to Table 2, the subsidies were stable over time but suddenly increased from 2014 to 2015 to $0.9 \%$ of the GDP due to the settlement of the delayed payments. Accurate estimates from the Secretariat of Economic Policy indicate $0.8 \%$ of the GDP in financial and credit subsidies since at least 2012.

As part of the counter-cyclical measures, the BNDES used to lend to private enterprises and offer low interest rates; the National Treasury was committed to equalizing the interest rates. For instance, the BNDES provided subsidized long-term credit for investments in machinery and the infrastructure sector. The difference between the benchmark rate Selic and the long-term interest rate, TJLP, define the size of the subsidy offered by the BNDES. The larger the difference is between the two rates, the larger the subsidy is. According to the Secretariat of Economic Policy, the total amount of such subsidies will reach $\mathrm{R} \$ 325$ billion in the next few decades.

Table 2: Primary Government Spending (1997-2015), \% of GDP

\begin{tabular}{|c|c|c|c|c|c|c|}
\hline & $\begin{array}{c}1997 \\
(\% \text { GDP }\end{array}$ & $\begin{array}{c}2002 \\
(\% \text { GDP) }\end{array}$ & $\begin{array}{c}2010 \\
(\% \text { GDP })\end{array}$ & $\begin{array}{c}2015 \\
(\% \text { GDP) }\end{array}$ & \begin{tabular}{|l} 
Variation \\
$1997-2015$
\end{tabular} & $\begin{array}{l}\text { Variation } \\
\text { 2011-2015 }\end{array}$ \\
\hline PRIMARY SPENDING & 14.00 & 15.90 & 18.10 & 19.30 & 5.30 & 1.20 \\
\hline Payroll & 4.50 & 4.90 & 4.30 & 4.00 & -0.50 & -0.30 \\
\hline Income Transfer to Households & 5.40 & 6.50 & 8.40 & 9.40 & 4.00 & 1.00 \\
\hline Pension Benefits & 4.90 & 5.90 & 6.60 & 7.40 & 2.50 & 0.80 \\
\hline Unemployment Insurance and Wage Bonus & 0.50 & 0.50 & 0.80 & 0.80 & 0.30 & 0.00 \\
\hline Elderly/Disabled Benefits (LOAS/RMV) & 0.00 & 0.00 & 0.60 & 0.70 & 0.70 & 0.10 \\
\hline $\begin{array}{l}\text { Bolsa-Família (conditional } \\
\text { income transfer program) }\end{array}$ & 0.00 & 0.10 & 0.40 & 0.50 & 0.50 & 0.10 \\
\hline Investments & 0.70 & 0.82 & 1.17 & 1.30 & 0.60 & 0.13 \\
\hline Fixed Gross Capital Formation & 0.70 & 0.82 & 1.15 & 1.04 & 0.34 & -0.11 \\
\hline Minha Casa Minha Vida (housing program) & 0.00 & 0.00 & 0.02 & 0.30 & 0.30 & 0.28 \\
\hline Expenditures & 2.20 & 2.80 & 4.10 & 3.70 & 1.50 & -0.40 \\
\hline Health & 1.00 & 1.30 & 1.30 & 1.40 & 0.40 & 0.10 \\
\hline Education & 0.10 & 0.30 & 0.50 & 0.60 & 0.50 & 0.10 \\
\hline Subsidies* & 0.10 & 0.10 & 0.10 & 0.90 & 0.80 & 0.80 \\
\hline Others & 1.00 & 1.10 & 2.20 & 0.80 & -0.20 & -1.40 \\
\hline Net Revenue & 14.20 & 18.00 & 20.20 & 17.60 & 3.40 & -2.60 \\
\hline Net Revenue minus IncomeTransfer & 8.80 & 11.50 & 11.80 & 8.20 & -0.60 & -3.60 \\
\hline
\end{tabular}

Source: National Treasury and IBGE. The calculations were conducted by the author.

Note: * Here, subsidies take into consideration only amounts due to the corresponding years. Implicit and explicit subsidies, that is, the financial and credit subsidies, began to be estimated only in 2012; since then, they represent $0.9 \%$ of the GDP in annual averages, according to the methodology developed by the Secretariat of Economic Policy from the Ministry of Finance. 
Therefore, protected by the Federal Constitution and laws, a growing number of beneficiaries, a sizable correction in the value of the benefits, enlarged income transfer programs, and the counter-cyclical fiscal policy can be considered the most relevant factors to explain the recent augmentation in government expenditures. At the same time, a drop in tax revenues, especially since 2014, has been sufficient to make the annual fiscal results vulnerable even though fiscal expansions were no longer financed by tax revenue.

Our main argument is that the 2014-2017 fiscal crisis is explained partly because of the colossal budget rigidity that originates from the latest Brazilian Federal Constitution (1988) and partly because of the social-based public policy implemented by the Lula government in the early 2000s and the counter-cyclical policies after the 2008 crisis. On the one hand, the determination to reduce poverty created a large income transfer program that was prone to sharp increases; on the other hand, the 2008 crisis was used as an opportunity to propose a number of nonconventional economic policies. Many stimuli were, wrongly or not, associated with a sort of traditional Keynesianism that was inspired by a simple domestic demand-based growth model. Most of the economic team at that time truly believed in the role played by the demand to escape from an economic crisis, without measuring solvency risks.

Additionally, the fiscal situation was exacerbated because the deficit in the pension system increased with unexpected quickness. After a certain period of stability, the deficit almost tripled from 2014 to 2017 , from $1 \%$ to $2.8 \%$ of the GDP. Part of the increasing deficit in the pension system is related to the economic contraction, which led to lowered tax revenues due to the deterioration in the labor market. However, the demographic dynamics of Brazil are a challenging issue for the pension system because the population is aging quickly. This issue is likely to be the primary explanation for the growth in the pension system expenditure in the coming years.

The deficit in the pension system related to the rural area is approximately equal the entire deficit of the system. Moreover, 6.0 million rural beneficiaries are not regular contributors to the system. They represent $64 \%$ of the pension beneficiaries in terms of retirement for the aging. On the other hand, most urban beneficiaries retire according to the time of contribution. A total of 15.1 million out of 32.7 million beneficiaries in the Brazilian pension system ${ }^{12}$ are retired, which is related to both age and the time of contribution and comprises $52 \%$ of the total pension spending; the remaining spending is associated with a comprehensive net

\footnotetext{
${ }^{12}$ Herein, we are focused only on the so-called "Regime Geral de Previdência Social (RGPS)", that is, the general regime of social security that covers the private sector workforce. This program is financed through payroll taxes and is shared by the employer and the employee, sales taxes revenues and federal transfers that cover the shortfalls of the system. In Brazil, there is another program for public sector employees, who are covered by multiple special pension regimes at different governmental levels - the Regimes Próprios de Previdência Social (RPPS). Municipal, federal and state entities manage their own schemes for their employees using a percentage of their salaries.
} 
of social protections such as widow/widower pensions, elderly and disability assistance and illness assistance. As the most important primary spending and because of its recent risky dynamic, the pension system requires urgent reform.

Consequently, the fiscal deterioration brought up the debt problem. The general government gross debt reached $74 \%$ of the GDP in 2017 , from $53 \%$, in 2013 , and annual primary deficits have occurred since 2014, after more than a decade of surpluses. Because of this new debt dynamic, many academics have begun to support the idea of fiscal dominance in the way Blanchard (2004) defined the situation that the Brazilian economy found itself in 2002.

According to Blanchard, "In 2002, the level and the composition of public debt in Brazil and the general level of risk aversion in world financial markets were indeed such as to imply the perverse effects of the interest rate on the exchange rate and on inflation". Additionally, "An increase in the real interest in response to higher inflation leads to a real depreciation. The real depreciation leads in turn to a further increase in inflation. In this case, fiscal policy, not monetary policy, is the right instrument to decrease inflation". Indeed, the monetary policy currently appears to be ineffective for keeping prices in check with higher rates, as opposed to a few years ago when it was effective to stimulate the economy with rate cuts.

From 2015 to 2016, the Brazilian economy seemed to experience similar conditions. As the Central Bank of Brazil increased the benchmark interest rate (Selic), the domestic currency was depreciating and therefore creating tension in the inflation rate. In such an anomalous circumstance, the monetary policy appears to be ineffective for taming inflation and inflation expectations; conversely, the Central Bank reaction shows a perverse effect of the interest rate on the exchange rate and inflation. In 2017, it was possible to refute an idea related to the fiscal dominance hypothesis as in Blanchard (2004), as the prices moved down rapidly, and interest rate accommodated this trend. The combination of political instability in the midst of an intensive process of price realignment seems to explain that puzzle.

\section{FAILURES TO IMPLEMENT FISCAL CONSOLIDATION PLANS}

In early 2015, Brazil launched a strict fiscal program. The pro-cyclical biased fiscal consolidation plan was presumably considered the only plausible policy stance when solvency rather than economic activity became the issue. In Brazil, the diagnosis and prescription had been far from divergent. However, would fiscal consolidation policies spur confidence so that the drag on economic activity could be avoided?

Broadly speaking, two groups of measures were announced. The first set of measures was announced in December 2014 and focused on reviewing some social benefits. At that time, the intention to both reduce the financial subsidies of BNDES (National Bank for Social and Economic Development) funding and, as prescheduled, the increase of taxes for industrialized goods, mainly in the automobile sector, was announced. In late January 2015 , a general increase in tax rates was announced 
(see the measures in Holland, 2015). A tax hike is a sort of once-and-for-all shock, and a spending cut may produce increasing savings over time, mainly because of changes in the criteria of eligibility for new beneficiaries.

According to Holland (2015), in the best-case scenario ${ }^{13}$, a theoretical positive fiscal impact of $2.0 \%$ of the GDP was estimated for 2015, when spending cuts supposedly responded to most of the fiscal retrenchment. Despite the political risks of its approval, it would be considered a promising beginning for a fiscal program. Such hypothetical fiscal efforts would be sufficient to transform a primary deficit of $0.6 \%$ of the GDP in 2014 into the then announced target surplus of $1.2 \%$ of the GDP in 2015. However, first, the tax revenue also responds to GDP growth ${ }^{14}$. Definitely, a contraction amounting to $3.8 \%$ of the GDP hardly offset the increase in tax revenue associated with the recent tax hikes. Additionally, partial congressional approval of the fiscal package lowered expectations for a reasonable 2015 fiscal result.

Using empirical findings as in Mendonça, Marçal and Holland $(2016)^{15}$, we can estimate the impacts of such fiscal announcements on output and confidence. We assume that $2.0 \%$ of the GDP is the size of the desired fiscal retrenchment; that is, $0.6 \%$ of the GDP in tax hikes and $1.4 \%$ of the GDP in spending cuts. According to our estimates, a $1 \%$ GDP change in government spending contributes up to 0.6 percentage points of the GDP change after four quarters in normal times. In this case, the 2015 proposal of fiscal retrenchment was theoretically to respond to a small part of a $3.8 \%$ contraction in 2015 . We are aware that this metric is not a terribly accurate measurement of that fiscal retrenchment - not because of our own skepticism of such empirical evidence but because there is no accurate timeline associated with the calendar year for econometrics. However, we can fairly conclude that this attempt at fiscal consolidation (2015) is not the main explanation for the recession. That proposed fiscal austerity was far from enough to reach appropriate results.

An avenue of literature supports the claim that the beneficiary effect of fiscal expansionary measures in difficult times has been underestimated; the stance of the business cycle and whether the fiscal policy is pro-cyclical or countercyclical have not been considered. According to Riera-Crichton et al., (2014), in difficult times, the spending multiplier is approximately 2.30 when there is a spending increase, which is much higher than our estimate.

The harmful effects of austerity in difficult times have also been underestimated

\footnotetext{
${ }^{13}$ This exercise considers the whole fiscal announcement, regardless of the fact that its effective impact will most likely be lower than expected because of changes during its legislative transit and timing.

14 The elasticity of tax income used to be considered greater than one; however, this figure became suspiciously lower than one, especially because of the structural change in the economy.

15 The authors use several models and specifications, based on the VAR approach; they were not able to identify a fiscal multiplier for spending greater than 0.6 for four quarters, which is very low according to the international experience.
} 
because the policy instrument (tax rates) has not been used. Instead, policy outcome measures based on tax revenue, such as cyclically adjusted measures, have been relied upon, as seen in the following equation: $\Delta$ cyclically - adjusted revenues $\equiv \% \Delta$ revenues $-\eta . \% \Delta G D P$, where $\eta$ is the tax base to GDP elasticity. When using $\Delta$ cyclically adjusted revenues, the result is not contractionary and can be neutral or even expansionary; however, when using $\Delta$ tax rates, the result is extremely contractionary (RieraCrichton et al.,, 2014).

The Brazilian economy has only recently moved to respond to the crisis using fiscal policy (Végh \& Vulletin, 2013). Until the 2008 financial crisis, Brazil was unable to introduce expansionary policy when the output gap was negative. The 2008 crisis proved that Brazilian solvency was no longer a major issue, and a comprehensive set of measures could help the country stymie the contamination of the worsening scenario experienced abroad and resume growth more quickly. The country context has already been discussed in a previous section.

We can learn two lessons here. First, there is a narrower-than-expected border to use both orientations (either counter or pro-cyclical) that is imposed by either the debt dynamic in the case of countercyclical fiscal policy or the real output and unemployment levels. Second, despite the orientation, there is no easy way to obtain sound fiscal results while swimming against the current. Along with frustrated growth $^{16}$, the fiscal situation was becoming worse, and solvency issues became a problem.

It is worth noting that, according to the literature, a long-term spending-based fiscal consolidation policy can be more effective than short-term tax-based policies, and the fiscal multiplier of the former is likely to be higher than that of the latter (Ilzetzki, 2011). According to Alesina et al., (2014), "Fiscal adjustments based upon spending cuts are much less costly in terms of output losses than tax-based losses and have especially low output costs when they consist of permanent rather than stop-and-go changes in taxes and spending". As the authors explain, "The difference between tax-based and spending-based adjustments appears not to be explained by accompanying policies, including monetary policy. It is mainly due to the different response of business confidence and private investment".

Our case study has not seen a multi-year fiscal plan, or a fiscal policy adjustment based on spending cuts. The only goal is to reach the annual announced primary surplus, regardless of the instrument and composition. Since the 2008 crisis, a relevant amount of one-off revenue has been used to deliver the announced primary surpluses.

It is difficult to identify the proportion of spending cuts and tax hikes needed to obtain surpluses. However, the fiscal measures announced in late 2014 and early 2015 defined approximately $2.0 \%$ of the GDP in overall savings through

\footnotetext{
16 The plausible reasons why the Brazilian economy was not able to resume growth even with fiscal stimulus are out of the scope of this work. However, we find little theoretical or empirical support for any association between the recent weakness and only one factor.
} 
spending cuts (approximately $1.4 \%$ of the GDP) and increased taxes (approximately $0.6 \%$ of the GDP). Undoubtedly, this value is overestimated, as it included cuts in an inflated budget. Taking into account only the structural spending cuts, the plan would retrench only $0.26 \%$ of the GDP, which is certainly a frustrated cut in comparison to the required one.

In 2016, the fiscal problems became even worse. Immersed in a huge political crisis, not a single fiscal measure was taken until an interim government took office. President Dilma Rousseff temporarily stepped aside to face an impeachment trial over allegations related to budgetary maneuvers. Just after taking office, the new President Michel Temer submitted to Congress a constitutional amendment bill limiting public spending. This constitutional amendment is based on a pledge to limit growth in government spending to the rate of inflation from the previous year. It also changes the growth rate of mandatory health and education spending by changing their indexation to inflation rate instead of the net current revenue.

Once again, the new administration insisted on avoiding tax increases. It only intended to review some remaining tax exemptions in line with what the previous government already addressed as its priority.

\section{WHAT SHOULD BE DONE?}

From 2014 to 2017, Brazil faced a very special case in comparison with international experiences. The fiscal deterioration was deep and prolonged. As demonstrated in the previous sections, the causes of such a fiscal crisis are multidimensional. Because of this, not one single policy stance would be consistent, that is, neither the long-term spending cut fiscal program nor the short-term tax hike measures would be suitable for such a reality. A particular combination of both could shorten the recession by recovering confidence faster. After the fiscal crises initiated, however, the governments that followed (the second term of Dilma followed by Temer) hesitated to simultaneously implement intensive cuts on government consumption and wide tax-hike measures.

For such circumstances, a more comprehensive fiscal framework that would fit better could be summarized in the following way.

First, the fiscal announcement has to be a "plan" for the future and a "shock" in fiscal results. Then, this article presents some reservation on the research conducted by Alesina et al., (2014). In their empirical findings, a multi-year spending-based fiscal plan is much less costly than a tax-based fiscal shock. According to the authors, "The difference between tax-based and spending-based adjustments appears not to be explained by accompanying policies, including monetary policy. It is mainly due to the different responses of business confidence and private investment".

In our country's case, it is worthy to announce a very wide tax hike policy, including new tax when possible. In our country's case, the plausible new tax would be the CPMF (a tax on financial transactions, which was already implemented decade ago). It is also expected to withdraw all tax exemptions, increase taxes on 
financial instruments and dividends, increase the rate of social security contributions, increase the rate of inheritance tax, etc. As an illustration, these measures would have produced additional tax revenue close to the primary deficits observed in 2017 and 2018.

On one hand, fiscal change announcements must be perceived as lasting longer than previous fiscal changes, such as the 2011 fiscal consolidation, and they have to be communicated with clear commitments. On the other hand, fiscal results, in this case, have to be achieved as soon as possible to convey that the policy is working well. Meanwhile, consistent fiscal policy has to anchor the long-term results. The new fiscal rule for the growth of primary government spending, already addressed by the Temer government, is in accordance with this recommendation.

However, neither Dilma's fiscal adjustment in her second term nor Temer's fiscal adjustment comprised both mechanisms of a suitable fiscal program in the way presented here. Temer was preoccupied with the spending trajectory, and Dilma had no sense of urgency for such an adjustment.

Therefore, as the second ingredient of a fiscal adjustment, we strongly suggest a rule for government spending dynamics over time, in line with what was approved by the Temer government, the spending ceiling. However, as most expenditures are mandatory, such as social and pension benefits, it is highly recommended to reform them before implementing that ceiling. This sequence of measures can meet the spending ceiling.

Finally, the fiscal plan tailored to the Brazilian case has to go beyond fiscal efforts and challenge itself to improve the relationship between the state and the private sector. Most state-owned companies ${ }^{17}$ should enter into the market to seek private strategic alliances, and a comprehensive program of privatization should occur. On the one hand, this move would make public accounting more transparent, and on the other hand, it would benefit fiscal results. However, the main purpose of such policy recommendations is to rebalance the broad spectrum of the state's involvement in the economy. Related to this, a new institutional framework should be developed, including an independent fiscal council.

The main corollary of such a fiscal plan would be a complete change in the incentives for investing and saving. The plan has to last for a sufficiently long period of time and must be deep and wide enough to attain such a goal. Therefore, both short - and long-term interest rates gradually decrease, thus promoting funding for long-term investment. Concurrently, the "short-termism mania" is being addressed; as well known, in Brazil, the persistently high inflation rates lead to high short-term real interest rates and fewer stimuli in the process of lengthening assets and liabilities.

It is important to reiterate that there is no simple and widespread fiscal rule that suits all countries well, as there is, for example, for central banks. Tailored

\footnotetext{
${ }^{17}$ According to the State-Owned Enterprises Observatory / FGV, Brazil has more than four hundred public companies, which is far more than the average of the members of the OECD.
} 
fiscal adjustments - according to each country's circumstances, even though they may seem discretionary at first glance - may also be more effective in reaching, sustaining, or even enhancing a country's credibility and reputation.

\section{FINAL REMARKS}

Fiscal policy was one of the most heavily disputed issues after the 2008 financial crisis. On the one hand, policymakers have been trying to reinvigorate growth and avoid the escalation of unemployment. Meanwhile, fiscal policy stances have oscillated between expansion and austerity with fragile assessments of their effectiveness.

Brazilian fiscal policy is remarkably contradictory. Early in the Lula administration, fiscal austerity was the only game in the town, and at the same time, there was a comprehensive public policy focused on reducing poverty and income inequality, which took government consumption on an increasing trajectory. The 2008 international crisis was the perfect excuse to expand the spending even more, now with subsidized credit and tax exemptions.

Dilma's government, in her first term, initially practiced austerity and asked monetary policy to ease without an accurate intertemporal assessment; further deterioration in the international scenario in 2012 suddenly made austerity old fashioned. Another tranche of counter-cyclical measures with questionable results for the economy was combined with maneuvers in the fiscal results, which were ruined with regard to the policymakers' credibility.

We supported the idea that the 2014-2017 fiscal crisis has multidimensional causes. It has its origin in the early 2000s, but it occurred because of government decisions to spend more on social programs and because of many counter-cyclical fiscal policies adopted in the aftermath of the 2008 financial crises. Political and moral crises added additional ingredients. Moreover, a sound institutional framework would have prevented excesses of spending.

In an effort to avoid further inconsistencies when manipulating fiscal policy and taking Brazil as a case study, this article proposed a wide fiscal framework with several components. A new institutional framework for the fiscal policy is welcome combined with a spending ceiling, reforms in the social benefits and in many special tax regimes, and an agenda of privatization and revision of the idea of gratuity in many public services. The lower the burden of the state is when providing benefits, the lower the tax burden in goods and services is.

We truly believe that only a comprehensive fiscal adjustment, combining spending cuts and reforms with tax hikes, would accelerate fiscal results and anchor confidence under circumstances like those experienced by the Brazilian economy during the period 2014-2017. 


\section{REFERENCES}

Alesina, A. and Ardgna, S. (2009) "Large chances in fiscal policy: taxes versus spending”. NBER Working Paper \#15438, October 2009.

Alesina, A., Favero, C. and Giavazzi, F. (2014). "The output effect of fiscal consolidation plan". (mimeo).

Alesina, A. and Ardgna, S. 2009. Large chances in fiscal policy: taxes versus spending. NBER Working Paper \#15438, October 2009.

Auerbach, A. and Gorodnichenko, Y. (2013). "Fiscal multipliers in recession and expansion". In A. Alesina and F. Giavazzi, org. Fiscal policy after the financial crises. NBER/Chicago Press.

Blanchard, O. (2004) "Fiscal Dominance and Inflation Targeting: Lessons from Brazil". NBER Working Paper No. 10389. March 2004

Eichengreen, B. (2015). Hall of Mirrors: the great depression, the great recession, and the uses - and misuses - of history. Oxford University Press.

Estevão, M. And Samake, I. (2013). "The Economic Effects of Fiscal Consolidation with Debt Feedback”. IMF Working Paper May 2013.

Favero, C., Giavazzi, F and J. Perego. 2011. "Country Heterogeneity and the International Evidence on the Effects of Fiscal Policy”. NBER Working Paper No. 17272. Issued in August 2011.

Holland, M. (2015). "Fiscal Policy in Brazil: from counter-cyclical to crisis". Working Paper 407, November 2015.

IMF. (2010). "Will it hurt? Macroeconomic effect of fiscal consolidation". World Economic Outlook (October). Washington, DC: IMF, chapter 3.

Ilzetzki E. et al.,, (2013). “How Big (Small?) Are Fiscal Multipliers?” Journal of Monetary Economics, Vol. 60, pp. 239-54.

Ilzetzki, E., (2011). "Fiscal Policy and Debt Dynamics in Developing Countries". Policy Research Working Paper Series 5666 (Washington: The World Bank).

Kraay, A., (2012). "How large is the Government Spending Multiplier? Evidence from World Bank Lending." Quarterly Journal of Economics, Vol. 127, No. 2, pp. 829-87.

Matheson, T and J. Pereira (2016) "Fiscal multipliers for Brazil". IMF working paper 79.

Mendonça, D., Marçal, e and Holland, M. (2016). "Is Fiscal Policy effective in Brazil? An empirical analysis”.EESP Working Paper. No 433. Novembro de 2016.

Mineshima, A. et al., (2014). "Size of Fiscal Multiplier". In C. Cottarelli, P. Gerson, and A. Senhaji, orgs. Post-Crisis Fiscal Policy. MIT Press.

Reinhart, C. et al., (2003). "Debt intolerance”. NBER Working Paper \# 9908, August 2003.

Riera-Crichton, D et al.,, G. (2014). "Procyclical and countercyclical fiscal multipliers: evidence from OECD countries". NBER Working Paper \#20533, September 2014.

Vègh, C. A. and G. Vuletin. (2013). "The Road to Redemption: Policy Response to Crises in Latin America”. IMF 14th Jacques Polak Annual Research Conference. IMF, Washington, DC. November 2013. 